\title{
Handicraft tourism in Kyrgyzstan: features and prospects
}

\author{
Chinara Beksultanova ${ }^{1}$, Zhanna Mazhitova ${ }^{1, *}$, Gulsunkan Zhunushalieva ${ }^{1}$, Lyazzat \\ Kozhakeyeva $^{3}$, Nazira Tentigul kyzy ${ }^{1}$, Fakiya Shamshidenova ${ }^{3}$ \\ ${ }^{1}$ Kyrgyz State Medical Academy, Bishkek, Kyrgyz Republic \\ ${ }^{2}$ Astana Medical University, Nur Sultan, Republic of Kazakhstan \\ ${ }^{3}$ Kazakh National Women's Teacher Training University, Almaty, Republic of Kazakhstan
}

\begin{abstract}
In the modern world, handicraft tourism is one of the developing types of tourism. The authors of this paper note that handicraft tourism is becoming more and more popular every year. Among other things the increasing number of tourists to the Kyrgyz Republic is associated with the manifestation of interest in the crafts and trades of the Kyrgyz. Handicraft tourism plays an important role as a tool for the preservation and development of the people's cultural heritage, contributes to the solution of population employment issues, stimulates an increase in the educational and cultural level of the population, blurs the boundaries between people. The article reveals the developmental characteristics of handicraft skills of the Kyrgyz as a part of traditional culture. The properties of wool, the technology of making felt, the combination of color shades, the placement of patterns on the felt, as well as their change in modern conditions are described. It is concluded that felt carpets, which have absorbed aesthetic and practical functions, have always been distinguished by their environmental friendliness and naturalness. The authors are convinced that these valuable qualities of handicraft products provide an opportunity for the development of handicraft tourism, in the future, as one of the priority areas of the Kyrgyzstan economy. Over time, the craft culture of the republic can become a permanent and demanded product offered for consumption and use by tourists.
\end{abstract}

\section{Introduction}

Not so long ago, in the Soviet past, a comprehensive study of the peoples' traditional nomadic culture was considered ideologically harmful in the USSR, therefore, such studies were not in high demand in Soviet academia [1]. As a rule, these important components of spiritual culture were criticized, ignored and not seriously studied [2]. However, as it became clear at the present time, there were exceptions, thanks to which the given topic was nevertheless developed, preparing a certain intellectual basis for research in the postSoviet times. Today the world is changing so rapidly that it is difficult to preserve cultural identity in its global metamorphoses. In these conditions, an important task for the society

*Corresponding author: mazhitova_69@mail.ru 
is an attempt to preserve its "self" through the popularization of the ideas of national identity, through the preservation of the national code. One of the ways to achieve these goals is to develop handicraft tourism. Today, handicraft tourism is one of the priority areas of the Kyrgyz economy, which, in accordance with the definition of the International Society for Ecotourism (TIES), is presented as "responsible travel to natural areas that protect the environment, support the well-being of local residents, and involve interpretation and education" [3].

\section{Materials and Methods}

The research design will be based on the interdisciplinary nature of the topic and will be implemented at the intersection of cultural studies, regional studies, history and political science. Modern humanitarian research into the interaction of nomadic and sedentary peoples is based on the methodology of interdisciplinary synthesis. This is due to the multifaceted and structurally complex nature of the methodological framework. At the present stage, in foreign and Central Asian studies, three macrolevel theoretical approaches prevail, i.e., formational, civilizational and modernization ones. In this paper, civilizational and modernization approaches will be used. The civilization paradigm recognizes polycentrism and diversity, focuses on the dynamics of local civilizations and cultures. The main focus of this theory is on the integrity of processes in society, due to the impact of various factors of integration. Modernization theory is aimed at considering structural changes as a result of various integration and disintegration processes.

The use of a systematic approach in the study is due to the understanding that the forms of traditional culture of the Kyrgyz constitute a self-sufficient system, at the same time acting as an integral element of the entire socio-cultural system of Kyrgyz society, directly and indirectly influencing the genesis and vector of development of society.

All approaches and research methods used in the project are organically interconnected aimed at achieving the set goal and the designated tasks.

\section{Discussion of the results}

\subsection{Ecotourism development}

Understanding the importance of handicraft and ecotourism for the economy and cultural space development, as well as for the tourism industry promotion and development, the Kyrgyz Republic Government approves on January 31, 2019 the Program of the Government for the Development of the Tourism Sector for 2019-2023 (hereinafter. - the Program) [4]. Each region of Kyrgyzstan is known by its diverse and attractive potential for the development of various types of tourism. It is no coincidence that the Government of the Republic is holding events aimed at attracting tourists to the region. For example, to attract tourists to the republic, various festivals are held, where meetings of representatives of the cultural and handicraft spheres with Kyrgyz and foreign tour operators are provided. As noted by D. Chochunbaeva, Director of the Resource Center of the Central Asian Association in Support of Crafts in Kyrgyzstan, it is necessary to strengthen the interaction of artisans and the tourism industry. Since 2006, the tradition of holding the international festival "Oimo" has been introduced in Kyrgyzstan, which has become a significant and bright event in the cultural life of the entire Central Asian region. Many travel companies in Central Asia include it in the calendar of regional events, which attracts an additional flow of tourists to the Kyrgyz Republic. The festival is provided with technical and financial support from various international and local organizations. For invited designers and 
artisans from Central Asian countries, the Oimo festival is a good sales market, and Kyrgyzstan is associated with a hospitable and welcoming home. Designers from all countries of the region show their models in the "ethno" style within the framework of the festival program. More than 100 craftsmen annually exhibit their products on the shelves of the craft fair, which spreads its tents in the continuation of the traditions of the Great Silk Way. Figures of culture and art, as well as amateur groups of the Assembly of the People of Kyrgyzstan, have the opportunity to perform and represent their ethnic culture during the festival days.

Another important event has become the festival "Kiyiz duinu" (“Кийиз дуйнө”) "The World of Felt". The festival program includes exhibitions of felt products and master classes held in the village of Kyzyl-Tuu, Ton district, Issyk-Kul region [5]. In the opinion of the state bodies of the republic, an active policy in this direction should attract an annually increasing number of tourists to the republic. The growth dynamics of potential tourists is reflected in the Program. Table 1. [4].

Table 1. The number of foreign tourists entering the Kyrgyz Republic.

\begin{tabular}{|c|c|c|}
\hline № & Year & Number of tourists \\
\hline 1 & 2019 & 4800 \\
\hline 2 & 2020 & 5100 \\
\hline 3 & 2021 & 5300 \\
\hline 4 & 2022 & 5600 \\
\hline 5 & 2023 & 6000 \\
\hline
\end{tabular}

The contribution of the tourism industry to the GDP of the Kyrgyz Republic in 2019 was $5.3 \%$, in 2023, judging by Table 2, it should increase to $7.0 \%$. However, it is now difficult to predict how optimistic these plans are, since it is difficult to plan this sphere for the future due to the coronavirus pandemic. Table 2 [4].

Table 2. Share of GDP in tourism.

\begin{tabular}{|c|c|c|}
\hline № & Year & Share of GDP \\
\hline 1 & 2019 & $5.3 \%$ \\
\hline 2 & 2020 & $5.6 \%$ \\
\hline 3 & 2021 & $6.0 \%$ \\
\hline 4 & 2022 & $6.5 \%$ \\
\hline 5 & 2023 & $7.0 \%$ \\
\hline
\end{tabular}

Every two years, the World Economic Forum (hereinafter - WEF) publishes a report on the development of the tourism industry in 140 countries. When compiling the rating, such indicators as safety, business climate, the level of development of medicine and hygiene, human resources and the labor market, the development of information technologies, the international openness of the country, the competitiveness of price proposals, the ecology of the country, the priority of the tourism and travel industry for the country's economy, the infrastructure of air transport, infrastructure of land transport and ports, the development of tourism infrastructure in the country, cultural resources, the level of development of business tourism, etc. are assessed. Among the post-Soviet republics, the rating is topped by Russia, Kazakhstan took 80th place. Kyrgyzstan got the worst overall assessment of tourism competitiveness among all the countries of the former USSR - 110th place of the rating [6]. This means that the republic has a lot of work to do to positively resolve issues that are included as indicators of the rating, improving its position. Table 3 [4]. 
Table 3. Place of the Kyrgyz Republic in the WEF rating for tourism development.

\begin{tabular}{|c|c|c|}
\hline № & Year & Place \\
\hline 1 & 2019 & 110 \\
\hline 2 & 2021 & 80 \\
\hline 3 & 2023 & 70 \\
\hline
\end{tabular}

\subsection{Special protection areas}

One of the important indicators of the WEF is the country's ecology, ecological infrastructure, environmental sustainability, the sphere of protection and safety of tourists. Therefore, it is no coincidence that today the problem of environmentally oriented tourism in the Kyrgyz Republic should be developed taking into account current environmental requirements [7].

The Law of the Kyrgyz Republic "On Special Protection Natural Areas" defines the regime for the use of special protection natural areas (hereinafter. - SPNAs) in tourism activities. Protected areas are used for the development of ecological tourism, involving the local population in the formation of tourist infrastructure and ensuring its sustainable functioning, as well as for acquaintance with the natural, historical and cultural attractions of the area. In SPNAs, it is allowed to organize and arrange excursion ecological routes, tourist trails and parking lots, place tourism objects, museums and open-air expositions in specially designated areas, depending on the regime of the established zone. There are a number of special protection natural areas in the republic, occupying $6 \%$ of the country's area, including 1 biosphere territory, 10 state conservation areas, 10 natural national parks, 68 reserves. Table 4 .

Table 4. Conservation areas. National parks. Reserves of the Kyrgyz Republic [8].

\begin{tabular}{|c|c|c|c|c|c|c|}
\hline $\begin{array}{c}\text { Number of natural } \\
\text { national parks, } \\
\text { units }\end{array}$ & 9 & 9 & 9 & 9 & 10 & 10 \\
\hline $\begin{array}{c}\text { area, thousand } \\
\text { hectares }\end{array}$ & 304.4 & 304.5 & 304.5 & 304.5 & 363.6 & - \\
\hline $\begin{array}{c}\text { Number of } \\
\text { reserves, units }\end{array}$ & 10 & 10 & 10 & 10 & 9 & 10 \\
\hline $\begin{array}{c}\text { area, thousand } \\
\text { hectares }\end{array}$ & 503.8 & 503.9 & 591.1 & 610.4 & 551.4 & 564 \\
\hline $\begin{array}{c}\text { Number of } \\
\text { hunting farms } \\
\text { units }\end{array}$ & 35 & 41 & 47 & 49 & 50 & 50 \\
\hline $\begin{array}{c}\text { area, thousand } \\
\text { hectares }\end{array}$ & - & 12.4 & 12.7 & 12.8 & 12.8 & 12.8 \\
\hline
\end{tabular}

There are 1923 most beautiful lakes in the Kyrgyz Republic, the main of which is Lake Issyk-Kul, which is one of the largest and deepest alpine lakes in the world; more than 40 thousand rivers, the main source of water in which is the melt water of mountain glaciers. The republic is among the 200 priority ecological regions of the planet. The Kyrgyz Republic is located along the Great Silk Way, on the roads of which there are 583 historical and cultural monuments and archaeological sites, some of which (Nevaket, Suyab, Balasagyn, Sulaiman-Too) are of world importance included in the UNESCO World Heritage List.

The territory of the country is one of the oldest centers of human civilization. The Kyrgyz, an ethnos known in Central Asia already in the first millennium BC, have brought 
their identity and culture through the centuries to the present day. Certain objects of intangible cultural heritage, such as the trilogy of the epic "Manas", the traditional dwelling of nomadic people's "Yurt", types of felt carpet "Shyrdak" and "Ala kiyiz" are included in the UNESCO World Heritage List.

Unfortunately, at the moment, the tourism industry in the republic is developing slowly, as it receives little investment. In the early 2000 s, on average, about 450,000 tourists came annually, mainly from the countries of the former Soviet Union. In 2018, the British backpacker society ranked Kyrgyzstan as the fifth best adventure travel destination in the world, claiming the country is the secret of adventure.

The popular science "National Geographic" magazine has named eight wild places in Kyrgyzstan that are recommended for tourists. "There are many Soviet-style buildings, spacious markets and colorful mosques in the cities of Kyrgyzstan. However, outside Bishkek and Osh, you will see a miracle - alpine lakes, snow-capped peaks and walnut forests," the newspaper wrote. National Geographic magazine has included several locations in its selection list.

Currently, meaningful and adventurous types of tourism that require active modes of movement (walking, water, mountain, cycling, skiing, etc.) are gaining in popularity. At the same time, an excessive and uncontrolled flow of tourists often leads to a negative impact on the environment, a decrease in biological and cultural diversity. From the point of view of ecology, in the field of tourism there are the following problems, namely, pollution of the environment, in particular, household waste; lack of sanitary and epidemiological requirements for temporary tourist camps; non-observance of the rules of environmental protection in protected areas [9].

\subsection{Crafts as elements of ecotourism development}

In the modern world, there is a growing interest in folk art of various forms, which reflect the original life of the people, its culture, and economic activity. Throughout their history, nomads have managed to create their own distinct culture, which attracts the attention of both foreign and domestic tourists. Folk art products combine the originality of the culture of the Kyrgyz people, convey the national flavor of the people. This is wood carving, and products made of felt, leather, bones, wood. Folk crafts in the modern world are not only cultural monuments, but also a factor that attracts tourists from all over the world.

The issue of the handicraft tourism development has been little studied, since this direction is quite new. According to A.V. Shestakov, "Handicraft tourism is a specialized program tourism focused on the study of folk crafts and handicrafts, familiarization and revival of ancient technologies and artistic traditions of folk art" [10]. We can say that handicraft tourism is a type of entertainment and educational tourism based on the study of folk crafts and handicrafts in the immediate places of their origin with the aim of learning, revitalizing and popularizing handicraft art. The purpose of this type of tourism in the Kyrgyz Republic is to form among tourists the perception of the uniqueness and diversity of the country both in the local socio-cultural space and abroad. Unfortunately, tourists have little information about the craft and cultural diversity of the republic. In our opinion, this factor is one of the main obstacles in the development of this type of tourism. This is due primarily to objective circumstances. First of all, those wishing to travel around the republic are provided with a minimum of information, as a rule, only from Internet resources. Further, it should be noted the weak legislative framework regulating this type of tourism. Moreover, an important factor should be noted, which is the lack of economic support for handicraft tourism from the state. Thus, handicraft management rests on the shoulders of artisans themselves, which significantly hinders the development of this direction of handicraft tour. 
The Kyrgyz craft has a rich history. Its roots lie in folk crafts that met the daily needs of a person. People who were able to make a good, a product, both for their own needs and for sale, were engaged in the craft. Each region of the Kyrgyz Republic has its own characteristics, history of development, and almost every region has a unique craft which is characteristic for this region. At the same time, the nomadic and semi-nomadic economy of the Kyrgyz influenced the nature of the handicraft's development and, of course, predetermined the use of environmentally friendly, natural livestock raw materials, i.e., sheep wool in the manufacture and decoration of traditional dwellings, clothing and household items [11].

Of course, the result of a person's handicraft activity can be obtained from various sources, including electronic ones. But we are sure that in the modern world, which is going through difficult times after the quarantine measures introduced by the states, the folk wisdom does not age: "it is better to see once than hear a hundred times". Therefore, the republic, interested in attracting tourists, must competently and functionally plan and develop special projects and events that contribute to the comprehensive dissemination of information about the region. One of the main directions of the handicraft tour is associated with acquaintance with national crafts for the production of wool and wood products.

Kyrgyz culture is based on nomadic traditions dating back to the times of the Mongol tribes. Although modern Kyrgyz live mainly in houses or apartment buildings, in the summer you can still observe how the indigenous people live in a yurt with their herds of sheep, goats, horses, and sometimes even yaks. There are several yurt camps in each area that cater to tourists; some of the most visible (and distant) are in Tash-Rabat, the "house of stones" in the Naryn region outside the city of Naryn, and in the Jeti-Oguz ("Seven Bulls") valley in the Jeti-Oguz region near the town of Karakol on Lake Issyk. Kul.

The Kyrgyz preferred autumn-cut wool, as it is more resilient, durable and elastic, and has a crimped fiber. This quality of wool contributes to the production of loose fluffy and elastic yarn, therefore, the life of the felt product increases. Due to their good elasticity, the products retain their good appearance for a long time. Any wool is hygroscopic, i.e. able to absorb water. At high humidity, it can absorb up to $33 \%$ moisture relative to its own weight, without being wet to the touch, it slowly releases it into the environment [12].

The main substance that makes up wool is keratin, which belongs to the group of protein substances. Due to its special properties, wool maintains those climatic conditions that are necessary for the body [11]. To this day, Kyrgyz men wear caps made of white sheep wool, which protect their heads from the scorching sun during the day and from the cold at night.

Also, wool is weakly electrified and does not retain dust particles, and despite its scaly structure and natural curliness, it belongs to smooth fibers. Wool repels water and other liquids, therefore, due to the large volume of air trapped in the wool, water easily passes through it and dissolves dirt.

The use of ornamented felt items (Kyrgyz - ala-kiyiz, Kazakh - kiiz), two-layer decorated, quilted carpets (Kyrgyz - shyrdak; Kazakh - syrmak) in Kyrgyz families is of great importance to this day, as they are part of the home interior or dowry of the bride.

In handicraft production, female labor prevailed, requiring great skills and patience. The women possessed the skills of making items for the interior decoration of a yurt, making felt, leather, woven carpets and mats. Almost everyone knew how to sew clothes, embroidered wall carpets. Undoubtedly, things and objects surpassed each other in beauty, color combination, ornamentation indicated the high skill of a woman who was respectfully called "cheber". The skills of needlework were mostly passed on by inheritance, from mother to daughter. However, rarely well-known craftswomen in the district still passed on their knowledge to other students [13, p. 28]. To make felt ("kiyiz", "ala kiyiz"), "ashar", a well-known custom of collective assistance, was widely used. According to this custom - 
kiyiz ashar, on the day the felt is made, relatives or neighbors come to help the craftswoman.

Male masters named "Usta" were subdivided according to their specific specialty, i.e., "zhygach usta" - a woodworker, "temir usta" - a blacksmith, "kumysh usta", "zerger" - a jewelry master, "bulgarychy" - a leather master [14]. However, this division was conditional, since the "usta" possessed the skills and abilities in many branches of handicraft. Thus, a wood craftsman made wooden parts for yurts, musical instruments, plows, baby cradles, and wooden household utensils. Blacksmiths forged iron, made horseshoes, metal utensils, and iron plaques on horse harness, but they also had skills in jewelry making.

Weaving, wickerwork, embroidery, jewelry, leather and wood products created by Kyrgyz craftsmen were distinguished by high decoration, therefore ornament was of great importance [15]. The combination of various shades of color, the placement of patterns on the felt, the choice of the background filling and the edges of the felt product have never been exactly repeated, were, in general, a reflection of the craftswoman's worldview.

Felt has always been indispensable in everyday life, as it protected a person and their home from cold, rain, wind, sun [16, p. 85]. The use of felt products in Kyrgyz families is of great importance to this day.

For the manufacture of felt, skillful oymochu craftswomen must be invited, who think over the ornament, choose the colors of the composition, apply patterns on the felt, lay out the wool.

The production of felt consists of several stages: the wool was washed, dried, beaten with twigs (saboo), laid out in two or three layers on a mat made of chiy, sprinkled with hot water, rolled into a roll, tied with a strong rope (arkan) and rolled for a long time and pressed with using the legs and elbows [13]. During the felting process, the roll was sprinkled with hot water several times.

The ornamented ala kiyiz felt is made by rolling in a colored pattern from dyed wool, or by laying out a colored cord. For staining, dyes of plant origin were used: roots, stems, fruits. They were dried, pounded and used as powders. So, green was obtained by boiling nut leaves, brown - from a decoction of a nut shell, red shades were given by wild poppy flowers and sprigs of blue plum, and yellow - from a decoction of onion husks. The most common colors among the Kyrgyz were blue (kok), red (kyzyl), yellow (sary) [13]. It should be noted that by the end of the 19th century vegetable dyes were replaced by artificial industrial dyes, which deteriorated the quality of the products.

Ala kiyiz, made by the method of embedding a pattern, reach sizes from one meter in width to one and a half meters in length, from three meters in width to five meters in length. The basis was two layers of wool, and the first layer consisted of autumn wool, the second one - of spring and autumn wool. On this basis, a pattern is laid out of wool dyed in two or three colors, after the tumble in, after the pattern turned out it became a little blurry [12]. The motives of the ornament were various curls, wavy and geometric lines.

Shyrdak (shyrdamal) is a thin and dense felt measuring from one and a half meters in width to two meters in length, or from two meters in width to four meters in length, made by the method of mosaic technique, quilting, application with a colored cord [11]. The mosaic technique predetermines the simultaneous stitching of the edges of two felt, contrastingly colored and cut out with a sharp knife or scissors, ornamental details. The seam on top is masked by sewing on a variegated cord made of pink, orange, red or white wool by twisting two threads of different colors in opposite directions. The product, consisting of two parts of the same ornament and contrasting in color, is characterized by the correspondence between the area of the background and the pattern, a sharp and accurate contour of the pattern. The main pattern is "whorl" ("kochkor muyuz") translated as "ram's horn", can be presented in various versions, arranged in a rectangle, triangle, 
rhombus [17, p. 27]. The ornamented border along the edges of the shyrdak was made in the form of rhythmically repeating patterns "kyyal", "karga tyrmak", "kush kanat", "kochkorok".

The ethnographic field studies carried out by the authors of the article in 2010-2019 showed that felting is most developed in the Issyk-Kul and Naryn regions of Kyrgyzstan, and also revealed new trends in the craft sector [18]. So, instead of the rich hand-made embroidery of tush-kiyiz, which requires intensive labor and time, "modern replica" appeared there, such as tush-kiyiz in the "kurak" technique with the use of adhesive and shiny Chinese materials. There are also so-called "Sinized" shyrdaks, in which patterns from Chinese carpets and trays are used. Therefore, as Uzbek researchers note: "Preserving the originality of local schools of "purity" of art is an topical issue that can be resolved with the help of specialists in this field" [19].

It should be noted that market conditions, the process of globalization, changing living conditions have also affected the sphere of handicrafts [20]. Special combing machines for loosening and combing wool began to be used (it costs residents 45 som. $=\$ 0.56$ per 1 kg.). Small factories appeared, for example, "Runo Asia LLC", which has been producing felt of various thicknesses and colors since 2009.

Due to its naturalness, environmental friendliness and hypoallergenicity, designers and individual craftsmen paid great attention to wool. It should be noted that their products have the "UNESCO Quality Mark". Making felt carpets to order or for sale gives craftswomen the opportunity to improve their living conditions, helps them in their sustainable development, therefore we can say that it is artisans in Kyrgyzstan who are actively developing small and medium-sized businesses. Therefore, they are very interested in tourism to the Kyrgyz Republic.

\section{Conclusion}

At the present stage, the significance of the search for the traditional roots of Central Asian societies, influencing the development paths of states and their relationships, has significantly increased. In this regard, handicraft and eco-culture allow communities to carry their cultural mentality through the years and take a worthy place in the world community. To a certain extent, handicraft tourism contributes to the preservation of the cultural code of the nation, which allows accumulating its national values in the memory of the people.

In general, it can be said that craft tourism helps to appreciate and understand nature, local society and culture. In addition to this, it stimulates the economy by not only tax deductions to the country's budget, but also by preserving and strengthening biocultural diversity. Handicraft tourism can pave the way for empowering local communities to reduce poverty and achieve sustainability by enhancing the potential of their cultural wealth.

Handicraft tourism in special protection natural areas has a number of benefits that can generate research finding, provide economic benefits for host communities, create alternative sources of income and employment for local communities, and raise awareness of the conservation of natural and cultural values among local residents and among tourists.

Considering the touristic potential of the republic, we can confidently say that it can satisfy many requests of tourists. It should be noted that craft tourism is becoming more and more popular every year. The choice of the country for the craft tour is not accidental. The republic has the richest natural resources, sacred places, protected areas, picturesque lakes. Cattle breeding continues to be one of the main types of economic activity of the population. Therefore, we can conclude that the country is rich in natural resources that 
ensure the development of crafts in different directions, favorable for the development of this direction of tourism.

A number of efforts are currently being made in Kyrgyzstan to promote "environmentally friendly" tourism. The Helvetas Swiss cultural development organization has sponsored several similar projects, including "Shepard's Life" and "Community Tourism". Many travel companies in Kyrgyzstan understand that "eco" sounds very attractive to many tourists who come to their country, so they tend to use this word to describe their organization, even if they do nothing to promote events with "low impact on the environment" or to create a "non-marking" camping site. Visitors are attracted by the beauty of the environment. In 2010, Kyrgyzstan joined the Region Initiative (TRI), which is a three-regional association of tourism-related organizations. TRI functions as a link between three regions - South Asia, Central Asia and Eastern Europe, which is also joined by Armenia, Bangladesh, India, Georgia, Kazakhstan, Pakistan, Nepal, Tajikistan, Russia, Sri Lanka, Turkey, Ukraine and Uzbekistan.

\section{References}

1. Z.G. Saktaganova, Zh.S. Mazhitova, Y.N. Aimakhov et al., European Journal of Science and Theology 14(1), 103-114 (2018)

2. Zh.S. Mazhitova, Asian Social Science 10(20), 129-136 (2014)

3. Bulletin of the International Society for Ecotourism (Oslo, 2007)

4. http://www.ecotourism-russia.ru/www.ecotourism.org.

5. http://cbd.minjust.gov.kg/act/view/ru-ru/12942?cl=ru-ru

6. Field materials of the authors: Issyk-Kul, Naryn regions.

7. https://www.atorus.ru/news/press-centre/new/48399.html

8. T. Alimbaev, B. Omarova, B. Abzhapparova et al., E3S Web of Conferences 175, 1-9 (2020)

9. https://ecostan.kg/krasnaya-kniga-kyrgyzstana/55-zapovedniki-nacionalnye-parkizakazniki-kyrgyzstana.html

10. T. Alimbaev, Z. Mazhitova, C. Beksultanova, N. Tentigulkyzy, E3S Web of Conferences 175 (2020)

11. A.V. Shestakova, Handicraft tourism (Staropol, Stavropol State University, 2008)

12. E.I. Makhova, N.V. Cherkasova, Proceedings of the Institute of Ethnography 37, 45 (1958)

13. M.N. Lushchihin, Biological bases of the fleece formation (Frunze, Ilim, 1973)

14. K.I. Antipina, E.I. Makhova, Proceedings of the KAEE 5, 28 (1968)

15. A.F. Burkovsky, From the history of woodworking technology (Moscow, 1954)

16. S.V. Ivanov, E.I. Makhova, Materials of the 25th International Congress of Orientalists (Moscow, 1960)

17. S.M. Abramzon, Kirghiz and their ethnogenetic and historical-cultural relationships (Leningrad, 1971)

18. A.Yu. Malchick, The history of Kyrgyz folk applied art: the evolution of Kyrgyz ornament from ancient times to the twentieth century (Bishkek,2 005)

19. Field materials of the authors (Issyk-Kul, Naryn, Chui, Batken regions)

20. O.A. Ostonov, Economy of Central Asia 5(1) (2021)

21. A.Z. Zhaparov, K. Belek, Ethnographic review 1, 172 (2019) 